\title{
Analisis Portofolio Sumber Dana PT Bank X Sebagai Instrumen Optimalisasi Budgeting dan Pengambilan Strategi
}

\author{
Yudha Pradipta Putra \\ Alumni Departemen Manajemen Fakultas Ekonomi dan Manajemen \\ Institut Pertanian Bogor \\ Farida Ratna Dewi \\ Departemen Manajemen Fakultas Ekonomi dan Manajemen \\ Institut Pertanian Bogor \\ Rieda05@yahool.com
}

\begin{abstract}
The rising of credit expansion by PT Bank $X$ has an implication to the high needs of fund. The fund source of PT Bank $X$ derived from third party fund account and transfer fund among offices. Every funding source has advantages, disadvantages and cost which must be examined because it can affect the bank's income. The purposes of this research are: (1) to identify the funding structure of PT Bank X, (2) to analyze the effect of every funding source to the PT Bank $X$, and (3) to analyze how the portfolio funding structure can be used to the budgeting process and strategy formulation. The funding source of PT Bank $X$ consists of third party fund account and transfer fund among offices. In 2005-2007 period, transfer fund among offices gave the biggest contribution in the funding source portfolio. The demand deposit gave the biggest impact in the income. Saving deposit also gave the positive affect and significant. The cost of saving deposit is quite low. Although demand deposit and saving deposit are included as the unstable fund in the asset portfolio of PT Bank $X$, the potential and the growth level which are very high can help PT Bank $X$ to provide fund with low cost. Interest from the use of transfer fund among offices is quite big that give the negative impact to the income.
\end{abstract}

Key words: Funding Structure, Portfolio, Budgeting, Strategy.

\section{Pendahuluan}

Pembangunan ekonomi di suatu negara sangat bergantung kepada perkembangan dinamis dan kontribusi dari sektor perbankan. Bank memiliki peran utama sebagai lembaga intermediasi. Usaha bank sebagai lembaga intermediasi meliputi kegiatan menghimpun dan menyalurkan dana sebagai kegiatan pokok dan penyedia jasa-jasa bank sebagai kegiatan pendukung (Kasmir, 2004).

Bank X beroperasi sejak tahun 1965. Perubahan bentuk hukum dari PD menjadi PT pada tahun 1999 menuntut profesionalisme sebagai bank yang memiliki fungsi dan tugas sebagai penghimpun dana masyarakat untuk disalurkan kembali menjadi kredit dan pengelola seluruh kas daerah Provinsi Lampung dalam bentuk giro. 
Kantor Cabang Pembantu (KCP) Antasari adalah salah satu kantor cabang pembantu Bank $X$ yang beroperasi di Jalan Pangeran Antasari, Lampung. Pendiriannya dilakukan sebagai upaya perluasan pasar di daerah dengan sektor niaga paling maju di Kota Bandar lampung, yaitu kawasan niaga Sukarame-Antasari. Tabel 1 menunjukkan perkembangan DPK dan ekspansi kredit KCP Antasari sejak 2005-2007.

Tabel 1. Perkembangan DPK dan Ekspansi Kredit KCP Antasari

\begin{tabular}{ccc}
\hline Tahun & DPK & Ekspansi Kredit \\
\hline 2005 & 8.033 .953 .000 & 14.935 .424 .000 \\
2006 & 15.087 .435 .000 & 36.499 .082 .000 \\
2007 & 11.293 .000 .000 & 42.312 .000 .000 \\
\hline
\end{tabular}

Sumber: PT Bank X 2007, diolah.

Djinarto (2000) menyatakan bahwa keberhasilan usaha suatu bank dapat dilihat dari cara bank tersebut mengarahkan dan mengendalikan keterpaduan antara rekeningrekening neraca pada sisi assets serta liabilities, yang diolah sedemikian rupa dan hasilnya tercermin dalam rekening laba/rugi. Upaya ekspansi kredit dilakukan oleh PT Bank $X$ untuk meningkatkan laba. Kebijakan tersebut berimplikasi pada peningkatan jumlah kredit tersalur yang terus meningkat dengan rata-rata pertumbuhan $80 \%$ per tahun. Peningkatan ekspansi kredit oleh PT Bank X kemudian menuntut peningkatan sumber dana. Pada umumnya, sumber dana bank berasal dari simpanan giro, deposito, dan tabungan di samping sumber dana dari pemegang saham dan dana pinjaman likuiditas dari bank sentral.

Sepanjang periode 2005-2007, simpanan DPK sebagai salah satu bagian dalam portofolio sumber dana PT Bank $X$ belum mampu memenuhi kebutuhan dana untuk ekspansi kredit. Kebutuhan dana untuk melakukan ekspansi kredit selanjutnya dipenuhi PT Bank $X$ dengan menggunakan dana transfer antarkantor. Tiap sumber dana memiliki kelebihan dan kekurangan masing-masing, termasuk biaya dana yang harus diperhitungkan karena dapat mempengaruhi pendapatan. Riyadi (2004) menggolongkan dana pihak ketiga sebagai sumber dana berbiaya. Pemasaran produk DPK oleh PT Bank X selanjutnya perlu dilakukan dengan mempertimbangkan penyusunan portofolio sumber dana yang mampu mengoptimalkan pendapatan dengan kendala biaya.

Berdasarkan latar belakang yang dikemukakan sebelumnya, maka perumusan masalah adalah sebagai berikut:

1. Bagaimana komposisi sumber pendanaan PT Bank X?

2. Bagaimana pengaruh tiap sumber dana terhadap pendapatan bank?

3. Bagaimana aplikasi perencanaan portofolio sumber dana terhadap proses penganggaran dan pengambilan strategi?

Berdasarkan perumusan masalah di atas, maka tujuan penelitian ini adalah:

1. Mengetahui struktur pendanaan PT Bank X.

2. Menganalisis pengaruh tiap sumber dana terhadap pendapatan PT Bank X.

3. Menganalisis bagaimana perencanaan portofolio sumber dana dapat berguna untuk proses penganggaran dan pengambilan strategi.

\section{Metode Penelitian}


Perbaikan kinerja perbankan pascakrisis ekonomi dan moneter 1997/1998 diikuti oleh tumbuhnya persaingan bisnis di antara bank. Beragam produk dan layanan jasa keuangan baik untuk individu maupun kalangan usaha terus diciptakan, dikembangkan, dan didayagunakan. Produk bank pada sisi pasiva antara lain giro, tabungan, dan deposito. Sedangkan produk bank pada sisi aktiva adalah perkreditan, antara lain kredit modal kerja, kredit investasi, kredit konsumsi, kredit sindikasi, dan lain-lain. Jasa perbankan yang umumnya ditawarkan antara lain berupa jasa transfer, inkaso, kliring, safe deposit box, garansi bank, letter of credit (L/C), dan lain-lain.

Kunci keberhasilan manajemen bank adalah bagaimana bank tersebut mampu mengoptimalkan peranannya sebagai financial intermediary. Optimalisasi fungsi intermediasi dapat dilakukan salah satunya dengan melakukan manajemen dana bank. Kegiatan manajemen dana bank meliputi perencanaan, pelaksanaan, dan pengendalian terhadap penghimpunan dan pengalokasian dana dari masyarakat.

PT Bank $X$ dalam fungsinya sebagai kantor cabang pembantu memiliki sumber dana berupa giro swasta, tabungan, deposito, dan dana transfer dari kantor cabang utama. Analisis regresi berganda digunakan untuk melihat pengaruh perubahan sumber dana secara simultan dan parsial terhadap pendapatan operasional bank. Sedangkan analisis per komponen dan analisis tren digunakan sebagai alat bantu dalam melihat tren perkembangan pemasaran produk-produk pasiva dan aktiva. Penggunaan alat analisis ini bertujuan untuk menganalisis sumber dana dan optimalisasi manajemennya untuk proses penganggaran dan pengambilan strategi oleh PT Bank $X$.

Data yang digunakan dalam penelitian ini terdiri dari data primer dan data sekunder. Data primer diperoleh dari hasil observasi dan wawancara dengan pimpinan PT Bank X. Data sekunder berasal dari laporan keuangan bank periode 2005-2007, dokumen lembaga terkait, studi literatur, dan sumber lain.

Pengolahan dan analisis data menggunakan analisis regresi berganda, analisis tren, dan analisis per komponen. Analisis regresi berganda adalah analisis yang berkaitan dengan permodelan pengaruh peubah-peubah bebas $X$ terhadap peubah tak bebas $Y$ melalui persamaan matematis tertentu. Model regresi berganda ditunjukkan oleh persamaan berikut ini:

$$
Y=\beta_{0}+\beta_{1} X_{1}+\beta_{2} X_{2}+\beta_{3} X_{3}+\beta_{4} X_{4}+e \ldots \ldots
$$

Keterangan:

$Y=$ Nilai variabel dependen (pertumbuhan triwulan pendapatan operasional)

$\beta_{0}=$ Konstanta

$\mathrm{X}_{1}=$ Pertumbuhan triwulan giro swasta

$\mathrm{X}_{2}=$ Pertumbuhan triwulan tabungan

$X_{3}=$ Pertumbuhan triwulan deposito

$\mathrm{X}_{4}=$ Pertumbuhan triwulan dana transfer dari kantor cabang utama

$\beta_{1}=$ Koefisien regresi variabel $X_{1}$

$\beta_{2}=$ Koefisien regresi variabel $X_{2}$

$\beta_{3}=$ Koefisien regresi variabel $X_{3}$

$\beta_{4}=$ Koefisien regresi variabel $X_{4}$

$\mathrm{e}=$ Tingkat kesalahan (galat)

Mattjik dan Sumartajaya (2002) kemudian menjelaskan bahwa model regresi berganda harus memenuhi beberapa asumsi, yaitu residual menyebar saling bebas 
mengikuti sebaran normal, residual memiliki ragam homogen atau tidak terdapat masalah heteroskedastisitas, dan tidak adanya korelasi yang tinggi antarpeubah bebas. Karena itu, terlebih dahulu dilakukan pengujian asumsi klasik yang meliputi: (1) Uji normalitas, dilakukan dengan menggunakan statistik Kolgomorov-Smirnov. Residual dikatakan tidak berdistribusi normal jika nilai Kolgomorov-Smirnov (KS) $>\mathrm{KS}_{1-\alpha}$ pada sejumlah pengamatan (n) tertentu. (2) Uji multikolinearitas, dilakukan dengan mengevaluasi nilai variance inflation factor (VIF). Iriawan dan Astuti (2006) menyatakan bahwa multikolinearitas dapat diidentifikasi pada parameter yang memiliki nilai VIF $\geq 5$. (3) Uji autokorelasi, dilakukan dengan melakukan uji runtutan (run test), dalam hal ini model dikatakan tidak mengalami autokorelasi jika $\mathrm{p}$-value $<\alpha$ $(0,05)$. (4) Uji heteroskedastisitas, dilakukan dengan melihat plot residual. jika tidak ada pola yang jelas serta titik-titik menyebar di atas dan di bawah angka 0 pada sumbu $\mathrm{Y}$, maka tidak terjadi heteroskedastisitas.

Analisis tren bertujuan untuk membandingkan kegiatan usaha suatu bank, baik secara absolut maupun dalam bentuk relatif atas bagian kegiatan yang ada dengan kegiatan-kegiatan yang telah dicapai pada periode sebelumnya (Siska, 2004). Cara yang ditempuh dalam analisis tren adalah dengan membandingkan laporan satu periode dengan periode lainnya dengan pendekatan indeks dasar tunggal.

Hasil yang ingin diperoleh dari pendekatan ini adalah tingkat perbandingan antara triwulan pertama dengan triwulan berikutnya yang dianalisis. Juga akan diketahui berapa besar perkembangan keuangan dari triwulan yang dianalisis terhadap triwulan dasar. Dari analisis ini akan diperoleh suatu gambaran perkembangan pemasaran produk-produk aktiva dan pasiva yang dilakukan oleh Bank $X$ dan tren kenaikan atau penurunan komponen laba-rugi.

Analisis per komponen merupakan alat analisis yang memberikan gambaran secara relatif atau persentase terhadap komposisi masing-masing pos keuangan. Secara teknis, analisis per komponen dilakukan secara vertikal dengan membandingkan pospos laporan keuangan dalam suatu periode yang sama. Analisis ini dapat memberikan gambaran tentang perubahan yang terjadi dalam masing-masing pos dari tahun ke tahun dalam hubungannya dengan kegiatan totalnya. Selain itu, dapat pula diketahui komposisi atau kontribusi dari masing-masing pos dalam suatu bentuk perbandingan terhadap kegiatan total.

\section{Hasil Penelitian}

\section{III.1. Gambaran Umum Perusahaan}

Bank X Cabang Pembantu Antasari didirikan pada tahun 2004. Jumlah pegawai PT Bank X hingga saat ini meningkat dari 12 orang menjadi 19 orang pegawai. Hal ini sejalan dengan makin meningkatnya usaha PT Bank X.

PT Bank $X$ menyediakan beberapa layanan produk yang dapat diklasifikasikan menjadi produk simpanan dan produk pinjaman. Produk simpanan terdiri dari produk giro (giro dinas dan giro swasta), produk deposito, dan produk tabungan. Produk pinjaman terdiri dari kredit pegawai dan kredit komersil (kredit investasi dan kredit modal kerja).

Dalam perkembangannya, PT Bank $X$ memiliki tingkat perkembangan bisnis yang cukup baik. Hal ini ditandai dengan kemampuan PT Bank $X$ dalam memasarkan lini 
produk DPK dan melakukan ekspansi kredit. Ekspansi kredit yang tinggi oleh PT Bank X berimplikasi terhadap kebutuhan dana yang tinggi. Kebutuhan dana untuk melakukan ekspansi kredit dipenuhi PT Bank X dengan mengelola beberapa sumber dana. Gambar berikut menunjukkan komposisi sumber dana PT Bank X selama periode 2005-2007.

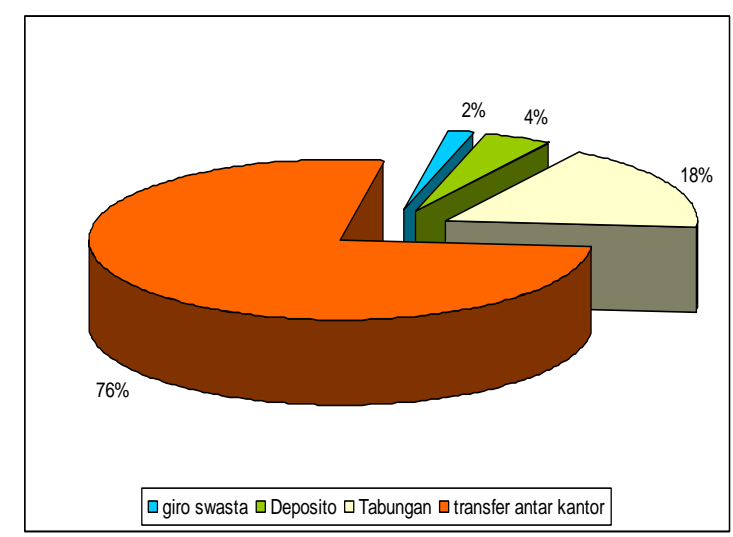

Gambar 1. Komposisi Sumber Dana PT Bank X Selama Periode 2005-2007

Sumber pendanaan PT Bank X terdiri dari pemasaran produk DPK (giro, tabungan, dan deposito) serta transfer dana dari kantor cabang utama. Pada periode 2005-2007, dana yang berasal dari transfer antarkantor memberikan kontribusi terbesar terhadap portofolio sumber dana PT Bank X sebesar 76\%. Sumber dana PT Bank X selanjutnya terdiri dari simpanan tabungan dengan kontribusi $18 \%$, deposito berjangka dengan kontribusi sebesar $4 \%$, dan giro swasta dengan kontribusi sebesar $2 \%$. Pada periode tersebut, posisi simpanan giro swasta memiliki tren menaik dengan rata-rata tingkat pertumbuhan paling tinggi dibandingkan produk DPK lainnya sebesar 47,19\% per triwulan. Produk tabungan tumbuh dengan rata-rata tingkat pertumbuhan 38,95\% per triwulan, sedangkan produk deposito memiliki rata-rata tingkat pertumbuhan sebesar $5,75 \%$ per triwulan.

\section{III.2. Penyusunan Model Portofolio Sumber Dana PT Bank X}

Nilai korelasi antarvariabel independen dapat digunakan untuk mendeteksi secara dini adanya multikolinearitas. Iriawan dan Astuti (2006) menyatakan bahwa multikolinearitas dalam kasus dapat dideteksi apabila: (1) terdapat korelasi yang kuat antarvariabel independen yang ditandai dengan nilai korelasi mendekati 1, dan (2) tanda parameter model berlawanan dengan tanda nilai korelasi antara variabel independen dengan variabel dependen.

Hasil analisis korelasi menunjukkan bahwa terdapat korelasi yang cukup erat antara variabel giro swasta dan variabel transfer antarkantor dengan nilai korelasi 0,792. Hal ini mengindikasikan adanya multikolinearitas jika model regresi dijalankan. Hasil pengolahan regresi berganda antara pendapatan sebagai variabel dependen dengan giro swasta, tabungan, deposito, dan transfer antarkantor sebagai variabel independen ditunjukkan oleh model pada persamaan 1 berikut:

Pendapatan $=-1.12 \mathrm{E}+10+52.4$ Giro Swasta +8.90 Tabungan + 1.33 Deposito -1.39 
Transfer Antarkantor

Dugaan adanya multikolinearitas kemudian diperkuat dengan adanya perbedaan tanda parameter model dengan tanda nilai korelasi antara variabel independen dan variabel dependen. Nilai korelasi variabel deposito dan giro swasta yang negatif terhadap pendapatan berlawanan dengan tanda parameter model giro swasta dan deposito yang positif. Nilai VIF variabel transfer antarkantor sebesar 5.0 pada model regresi menunjukkan adanya kendala multikolinearitas. Kendala multikolinearitas pada model dapat diatasi dengan menggunakan regresi stepwise.

Hasil pengolahan portofolio sumber dana PT Bank $X$ dengan metode regresi stepwise, menghasilkan model terbaik pada step ketiga dengan model 2 sebagai berikut:

$$
\text { Pendapatan }=-9.99 \mathrm{E}+09+46.8 \text { Giro Swasta }+8.70 \text { Tabungan } \ldots . . .(2)
$$

Dalam model tersebut, pendapatan akan dipengaruhi oleh tiga variabel independen, yaitu giro swasta, tabungan, dan transfer antarkantor. Variabel deposito tidak lagi tercantum dalam model. Perbandingan kriteria model terbaik antara model regresi awal (persamaan 1) dengan model regresi hasil stepwise (persamaan 2) ditunjukkan pada tabel 2 berikut:

Tabel 2. Perbandingan Kriteria Model Terbaik Antara Model Regresi Awal dengan Model Regresi Hasil Stepwise

\begin{tabular}{lll}
\hline \multicolumn{1}{c}{ Kriteria } & \multicolumn{1}{c}{ Model Awal } & \multicolumn{1}{c}{ Model Stepwise } \\
\hline S & 8515452159 & 8059764172 \\
R-Square (\%) & 89.6 & 89.32 \\
R-Square Adj (\%) & 83.6 & 85.32 \\
\hline
\end{tabular}

Berdasarkan tabel 2 dapat disimpulkan bahwa model hasil regresi stepwise lebih baik dari model regresi awal karena memiliki standar deviasi residual (S) yang lebih kecil sebesar 8059764172 dan nilai R-Square Adjusted yang lebih besar sebesar 85,3\%.

\section{III.3. Validasi Model Portofolio Sumber Dana PT Bank X}

Uji kolgomorov smirnov dilakukan menggunakan $\alpha$ sebesar $5 \%$. Nilai statistik $\mathrm{KS}_{1-\alpha}$ untuk $\alpha=0,05$ dan jumlah pengamatan sebanyak 12 pengamatan adalah 0,375 (uji 2 arah). Hasil pengujian menunjukkan bahwa nilai statistik kolgomorov-smirnov (KS) adalah 0,157 dan p-value uji normal residual grafik melebihi $15 \%$. Nilai statistik KS yang diperoleh dari pengamatan kurang dari nilai $\mathrm{KS}_{1-\alpha}$, sehingga disimpulkan bahwa residual model regresi portofolio sumber dana PT Bank $X$ yang dibuat telah memenuhi asumsi kenormalan.

Hasil pengujian menunjukkan bahwa nilai VIF dan p-value untuk semua variabel berada di bawah 5 , nilai ini mengindikasikan tidak terdapat masalah multikolinear dalam model.

Hasil run test (lampiran 1) menunjukkan bahwa $p$-value $=0,466$, sehingga $p$-value $>$ $\alpha(0,05)$. Hal ini menunjukkan bahwa tidak terdapat autokorelasi pada residual, sehingga asumsi kebebasan terpenuhi. 
Plot residual (lampiran 1) merupakan plot antara residual dengan dugaan respons. Dari plot tersebut terlihat bahwa titik-titik yang ada tidak membentuk pola tertentu, melainkan menyebar di atas dan di bawah angka 0 pada sumbu Y. Dengan demikian, dapat disimpulkan bahwa tidak terjadi heteroskedastisitas.

Uji F dilakukan untuk melihat pengaruh keseluruhan variabel independen terhadap variabel dependen. Variabel independen dikatakan berpengaruh secara keseluruhan jika $\mathrm{F}$ hitung $>\mathrm{F}$ tabel atau $\mathrm{F}$ hitung $<-\mathrm{F}$ tabel. Dengan taraf nyata $(\alpha=5 \%)$, didapat nilai $F$ tabel sebesar $F: 0,05(3,8)=4,07$.

Hasil perhitungan menunjukkan nilai $\mathrm{F}$ hitung sebesar 22,31. Hasil uji menunjukkan bahwa $F$ hitung $>F$ tabel, yaitu 22,31 > 4,07. Sehingga giro swasta (X1), tabungan (X2), dan transfer antarkantor (X3) secara keseluruhan berpengaruh secara signifikan terhadap pendapatan pada taraf nyata $5 \%$.

Uji t dilakukan untuk melihat pengaruh parsial antara variabel independen terhadap variabel dependen. Variabel independen dikatakan berpengaruh secara parsial jika $t$ hitung $>\mathrm{t}$ tabel atau $\mathrm{t}$ hitung $<-\mathrm{t}$ tabel. Dengan taraf nyata $(\alpha=5 \%)$, didapat nilai $\mathrm{t}$ tabel sebesar $t(\alpha / 2, d f)=t(0,025,8)=2,306$.

Hasil perhitungan menunjukkan bahwa t hitung untuk variabel $\mathrm{X} 1, \mathrm{X} 2, \mathrm{X} 3$ adalah masing-masing sebesar 2,$43 ; 7,84 ;-3,80$. Hasil uji menunjukkan bahwa nilai t hitung $>t$ tabel untuk variabel giro swasta (X1) dan tabungan (X2). Nilai t hitung < -t tabel untuk variabel transfer antarkantor (X3). Sehingga variabel giro swasta, tabungan, dan transfer antarkantor secara parsial berpengaruh secara signifikan terhadap pendapatan dengan taraf nyata $5 \%$.

\section{III.4. Hasil Dampak Perubahan Secara Parsial}

Hasil uji validasi terhadap model menunjukkan bahwa model portofolio sumber dana PT Bank $X$ telah memenuhi asumsi yang disyaratkan. Kebaikan model juga didukung oleh nilai standar deviasi residual, R-square, dan R-square adj yang cukup baik. Nilai R-square sebesar 89,32\% (tabel 2) menunjukkan bahwa 89,32\% keragaman dari variabel dependen (pendapatan) dapat dijelaskan oleh keragaman variable independen. Sedangkan sisanya sebesar 10,68\% dijelaskan oleh variabel lain di luar model yang tidak dijelaskan dalam penelitian ini. Tabel 3 menunjukkan dampak portofolio sumber dana terhadap pendapatan PT Bank X periode 2005-2007.

Tabel 3. Dampak Portofolio Sumber Dana terhadap Pendapatan PT Bank X Periode 2005-2007

\begin{tabular}{lrrr}
\hline \multicolumn{1}{c}{ Peubah Sektoral } & Koefisien Regresi & t-test & p-value \\
\hline Giro Swasta (X1) & 46,8 & 2,43 & 0,041 \\
Tabungan (X2) & 8,70 & 7,84 & 0,000 \\
Transfer Kantor (X3) & $-1,28$ & $-3,80$ & 0,005 \\
\hline
\end{tabular}

Terdapat pengaruh positif antara pemasaran produk giro swasta terhadap pendapatan PT Bank X yang ditunjukkan oleh koefisien regresi sebesar 46,8 (Tabel 4). $\mathrm{Hal}$ ini menunjukkan bahwa bila jumlah giro swasta dalam portofolio sumber dana bertambah 1 rupiah, maka pendapatan PT Bank X akan bertambah 46,8 rupiah (cateris paribus). Kondisi ini dapat dijelaskan sebagai berikut: (1) pemasaran produk giro swasta memiliki rata-rata tingkat pertumbuhan yang paling tinggi dibandingkan produk lain, yaitu sebesar rata-rata 47,19\% sepanjang periode $2005-2007$; (2) produk giro 
swasta memberikan kontribusi sebesar 10,12\% terhadap penghimpunan DPK. Jumlah tersebut masih memberikan kontribusi yang kecil dalam portofolio sumber dana PT Bank $X$, yaitu sebesar 2,86\%. Namun, analisis terhadap anggaran biaya bunga menunjukkan bahwa pemasaran produk giro swasta memberikan kontribusi yang paling kecil terhadap beban biaya bunga PT Bank X, yaitu sebesar 1,97\%.

Koefisien regresi produk tabungan yang bernilai 8,70 menunjukkan adanya pengaruh positif perkembangan jumlah tabungan terhadap pendapatan PT Bank X. Koefisien tersebut dapat diartikan bahwa bila jumlah tabungan dalam portofolio sumber dana bertambah 1 rupiah, maka pendapatan PT Bank $X$ akan bertambah 8,70 rupiah (cateris paribus). Kondisi ini dapat dijelaskan sebagai berikut: (1) pemasaran produk tabungan memiliki rata-rata tingkat pertumbuhan yang tinggi, yaitu sebesar rata-rata 38,95\% sepanjang periode 2005-2007; (2) produk tabungan memberikan kontribusi sebesar $61,02 \%$ terhadap penghimpunan DPK. Jumlah tersebut memberikan kontribusi yang cukup besar dalam portofolio sumber dana PT Bank X dibandingkan produk DPK lain, yaitu sebesar $17,26 \%$. Analisis terhadap anggaran biaya bunga menunjukkan bahwa pemasaran produk tabungan memberikan kontribusi sebesar $19,56 \%$ terhadap beban biaya bunga PT Bank X.

Hasil analisis menunjukkan bahwa produk tabungan termasuk produk penghimpun DPK dengan biaya rendah, dengan rata-rata beban bunga sebesar $4,5 \%$ per tahun. Biaya bunga yang rendah disertai tren pertumbuhan yang positif dan tinggi memberikan dampak positif dan signifikan terhadap pendapatan PT Bank X.

Terdapat pengaruh negatif antara penggunaan dana transfer antarkantor terhadap pendapatan PT Bank $X$ yang ditunjukkan oleh koefisien regresi -1,28. Hal ini menunjukkan bahwa bila jumlah dana yang berasal dari transfer antarkantor bertambah 1 rupiah, maka pendapatan PT Bank $X$ akan berkurang 1,28 rupiah (cateris paribus). Kondisi ini dapat dijelaskan sebagai berikut: (1) jumlah kredit yang disalurkan mengalami rata-rata pertumbuhan yang sangat tinggi masing-masing sebesar $74,10 \%$ untuk kredit pegawai dan 31,50\% untuk kredit konsumsi. Tingginya tingkat pertumbuhan kredit yang disalurkan tidak diimbangi dengan pertumbuhan posisi simpanan DPK. Hal ini kemudian berimplikasi terhadap meningkatnya penggunaan dana yang berasal dari transfer antar kantor. (2) Dana yang berasal dari transfer antarkantor memberikan kontribusi paling besar dalam portofolio sumber dana PT Bank X, yaitu sebesar $71,7 \%$. Analisis per komponen terhadap anggaran biaya bunga menunjukkan bahwa dana transfer antarkantor memberikan kontribusi beban bunga terbesar, dengan persentase 60,85\%.

Model terbaik hasil regresi stepwise menunjukkan bahwa produk deposito tidak dijelaskan oleh model portofolio sumber dana PT Bank X. Kondisi ini dapat dijelaskan sebagai berikut: (1) data historis pemasaran produk-produk aktiva dan pasiva PT Bank $X$ pada periode 2005-2007 menunjukkan bahwa pemasaran produk deposito memiliki rata-rata tingkat pertumbuhan yang sangat kecil dibandingkan produk lain, yaitu sebesar rata-rata 5,75\%; (2) produk deposito berjangka memberikan kontribusi sebesar $28,68 \%$ terhadap penghimpunan DPK. Jumlah tersebut memberikan kontribusi yang lebih baik dari simpanan giro dalam portofolio sumber dana PT Bank X, yaitu sebesar $8,18 \%$. Namun analisis terhadap anggaran biaya bunga menunjukkan bahwa produk deposito memberikan kontribusi yang besar dengan persentase mencapai 
17,62\% terhadap beban biaya bunga PT Bank X. Bila dibandingkan dengan produk penghimpun dana lainnya, produk deposito berjangka merupakan produk dengan biaya tinggi, dengan rata-rata beban bunga sebesar $8,6 \%$.

III.5. Optimalisasi Portofolio Sumber Dana Dalam Proses Penganggaran dan Pengambilan Strategi

Penyusunan rencana bisnis oleh PT Bank $X$ akan menjadi bentuk pertanggungjawaban kantor cabang kepada kantor pusat. Rencana bisnis akan dijadikan standar keberhasilan kantor yang menjadi acuan bagi kantor pusat untuk melakukan evaluasi terhadap tingkat kinerja KCP Antasari. Rencana bisnis kemudian dijadikan sebagai acuan pengambilan kebijakan. Dalam operasionalnya, rencana bisnis digunakan sebagai dasar pengambilan kebijakan ekspansi dan pembatasan kredit, serta kebijakan pengelolaan aset dan biaya operasional kantor.

Model portofolio sumber dana digunakan untuk mengoptimalkan pendapatan sebagai salah satu indikator sasaran dalam rencana bisnis PT Bank X. Dalam hal ini, pendapatan yang optimal dapat diwujudkan melalui pengelolaan asset dan liability dengan baik (Djinarto, 2000). Asset Liabilities Management (ALMA) diarahkan untuk menjaga gap positif antara pos-pos dalam aktiva yang peka terhadap perubahan tingkat bunga (rate sensitive asset) dengan pos-pos dalam pasiva yang peka terhadap perubahan tingkat bunga (rate sensitive liability).

Analisis terhadap rencana bisnis PT Bank X menunjukkan bahwa pada tahun 2007, komposisi rencana penghimpunan DPK terdiri dari 61\% simpanan tabungan, $29 \%$ simpanan deposito berjangka dan $10 \%$ simpanan giro. Komposisi ini mengalami perubahan dibandingkan penghimpunan DPK pada tahun 2006 yang terdiri dari $75 \%$ simpanan tabungan, $18,33 \%$ simpanan deposito berjangka, dan 6,3\% simpanan giro. Perubahan komposisi ini menunjukkan adanya kebijakan peningkatan simpanan deposito oleh PT Bank X.

Evaluasi terhadap portofolio sumber dana, menunjukkan bahwa jumlah simpanan giro swasta dan tabungan sebaiknya ditingkatkan karena merupakan sumber dana dengan biaya rendah, serta berpengaruh secara positif dan signifikan terhadap pendapatan. Sedangkan penggunaan dana yang berasal dari transfer antarkantor perlu dikurangi karena memberikan pengaruh yang negatif dan signifikan terhadap pendapatan. Peningkatan jumlah simpanan deposito berjangka selanjutnya perlu dievaluasi karena disertai dengan beban biaya bunga yang tinggi (rate sensitive liability).

Pengaruh positif dan signifikan produk giro swasta disebabkan oleh rata-rata pertumbuhan simpanan giro swasta yang sangat tinggi mencapai 47,19\%. Pertumbuhan produk giro swasta tidak diikuti dengan pertumbuhan biaya yang signifikan, karena data historis menunjukkan bahwa giro swasta merupakan produk penghimpun dana dengan biaya rendah sebesar rata-rata 3\% per tahun.

Analisis terhadap statistik ekonomi keuangan daerah Provinsi Lampung menunjukkan bahwa pada periode 2003-2007, posisi simpanan giro masyarakat mengalami pertumbuhan rata-rata $18,77 \%$. Pada periode tersebut, simpanan giro masyarakat kota Bandar Lampung paling tinggi dibandingkan daerah Dati II lainnya. 
Pada tahun 2007, simpanan giro di Kota Bandar Lampung mencapai 69,32\% dari total simpanan giro masyarakat di provinsi Lampung.

Sepanjang periode 2003-2007, kredit modal kerja mendominasi posisi pinjaman di Kota Bandar Lampung dengan persentase rata-rata sebesar $51 \%$. Tingginya kebutuhan kredit modal kerja, secara tidak langsung akan meningkatkan potensi simpanan giro sebagai salah satu media pengelolaan keuangan dalam operasional bisnis.

Potensi simpanan giro yang cukup besar di Kota Bandar lampung menunjukkan peluang bagi PT Bank $X$ untuk melakukan pemasaran yang intensif terhadap produk giro. Pada tahun 2007, posisi simpanan giro swasta di PT Bank $\mathrm{X}$ memberikan kontribusi sebesar $0,021 \%$ terhadap posisi simpanan giro masyarakat di Kota Bandar Lampung. Posisi simpanan giro swasta PT Bank $X$ akan berpotensi untuk terus ditingkatkan sebagai implikasi posisi Bank $X$ sebagai bank yang memiliki keterkaitan erat terhadap dunia usaha yang terkait dengan pemerintah daerah.

Pengaruh positif dan signifikan terhadap pendapatan juga ditunjukkan oleh produk tabungan. Data historis menunjukkan bahwa simpanan tabungan meningkat rata-rata $38,95 \%$ per triwulan. Selain itu, pertumbuhan produk tabungan juga tidak diikuti dengan pertumbuhan biaya yang signifikan, karena data historis menunjukkan bahwa produk tabungan termasuk produk penghimpun dana dengan biaya rendah sebesar rata-rata $4,5 \%$ per tahun.

Analisis terhadap statistik ekonomi keuangan daerah Provinsi Lampung menunjukkan bahwa pada periode 2003-2007, simpanan tabungan masyarakat di Kota Bandar Lampung tumbuh sebesar rata-rata 36\%. Pada tahun 2007, simpanan tabungan PT Bank $X$ memberikan kontribusi sebesar 0,24\% terhadap simpanan tabungan masyarakat di Kota Bandar Lampung. Persentase tersebut masih cukup kecil sebagai implikasi ketatnya persaingan, terutama dengan bank BUMN dan bank swasta nasional. Sebagai perbandingan, berdasarkan proporsi simpanan tabungan terhadap jumlah bank di kotamadya Bandar Lampung pada tahun 2007, PT Bank X idealnya mampu memberikan kontribusi sebesar $0,62 \%$ terhadap simpanan tabungan masyarakat di Kotamadya Bandar Lampung.

Jumlah simpanan tabungan PT Bank $X$ berpotensi untuk terus ditingkatkan dengan upaya pemasaran. Selain melalui upaya pemasaran, produk tabungan juga dapat ditingkatkan melalui ekspansi kredit, khususnya kredit pegawai. PT Bank $\mathrm{X}$ memiliki keunggulan dengan memberikan kontribusi sebesar 1,5\% terhadap total kredit konsumsi di Kotamadya Bandar Lampung lewat produk kredit pegawai. Peningkatan jumlah simpanan tabungan melalui ekspansi kredit dimungkinkan dengan adanya ketentuan pemotongan plafond kredit sebesar $10 \%$ untuk pembukaan rekening tabungan di PT Bank X.

\section{Kesimpulan}

Kebutuhan dana untuk melakukan ekspansi kredit dipenuhi PT Bank $\mathrm{X}$ dengan mengelola beberapa sumber dana. Sumber pendanaan PT Bank $X$ terdiri dari pemasaran produk DPK (giro swasta, tabungan dan deposito berjangka) serta transfer dana dari kantor cabang utama. Pada periode 2005-2007, dana yang berasal dari transfer antarkantor memberikan kontribusi terbesar terhadap portofolio sumber dana PT Bank $X$ sebesar 76\%. Sumber dana PT Bank $X$ selanjutnya terdiri dari simpanan 
tabungan dengan kontribusi $18 \%$, deposito berjangka dengan kontribusi sebesar $4 \%$, dan giro swasta dengan kontribusi sebesar $2 \%$. Pada periode tersebut, posisi simpanan giro swasta memiliki tren menaik dengan rata-rata tingkat pertumbuhan paling tinggi dibandingkan produk DPK lainnya sebesar 47,19\% per triwulan. Produk tabungan tumbuh dengan rata-rata tingkat pertumbuhan 38,95\% per triwulan, sedangkan produk deposito memiliki rata-rata tingkat pertumbuhan sebesar $5,75 \%$ per triwulan.

Berdasarkan hasil pengujian menggunakan uji $F$, disimpulkan bahwa secara keseluruhan portofolio sumber dana PT Bank X yang terdiri dari giro swasta, tabungan dan transfer antarkantor berpengaruh secara signifikan terhadap pendapatan. Berdasarkan hasil pengujian menggunakan uji t, disimpulkan bahwa secara parsial giro swasta dan tabungan berpengaruh secara positif dan signifikan terhadap pendapatan, sedangkan transfer antarkantor berpengaruh secara negatif dan signifikan terhadap pendapatan.

Model regresi portofolio sumber dana PT Bank $X$ menunjukkan bahwa produk giro swasta memberikan pengaruh paling besar terhadap pendapatan. Posisi produk giro swasta sebagai produk penghimpun DPK dengan biaya paling rendah sebesar rata-rata $3 \%$ per tahun memberikan pengaruh positif terhadap pendapatan. Pengaruh yang signifikan juga disebabkan oleh tren pertumbuhan produk giro swasta yang sangat tinggi pada periode 2005-2007. Pengaruh positif dan signifikan terhadap pendapatan juga ditunjukkan oleh produk tabungan. Pengaruh positif dan signifikan disebabkan oleh dominasi simpanan tabungan dalam komposisi DPK PT Bank X. Posisi produk tabungan sebagai produk penghimpun DPK dengan biaya rendah sebesar rata-rata 4,5\% per tahun memberikan pengaruh positif terhadap pendapatan. Pengaruh yang signifikan juga disebabkan oleh tren pertumbuhan produk tabungan yang cukup tinggi pada periode 2005-2007. Beban bunga yang cukup besar dari penggunaan dana transfer antarkantor memberikan pengaruh negatif terhadap pendapatan. Pengaruh signifikan disebabkan oleh penggunaan dana transfer antarkantor yang cukup besar sebagai implikasi belum mampunya PT Bank X meningkatkan sumber pendanaan yang berasal dari produk penghimpun DPK.

Penyusunan rencana bisnis oleh PT Bank $X$ menjadi bentuk pertanggungjawaban kantor cabang kepada kantor pusat. Rencana bisnis akan dijadikan standar keberhasilan kantor yang menjadi acuan bagi kantor pusat untuk melakukan evaluasi terhadap tingkat kinerja KCP Antasari. Model regresi portofolio sumber dana digunakan untuk mengoptimalkan pendapatan sebagai salah satu indikator sasaran dalam rencana bisnis PT Bank X. Model regresi portofolio sumber dana juga digunakan sebagai dasar pertimbangan dalam pengambilan kebijakan pengelolaan aset dan biaya operasional kantor serta kebijakan pemasaran produk-produk penghimpun DPK.

\section{Daftar Pustaka}

Anonim. 2004. Laporan Tahunan 2004. Bank X, Bandar Lampung.

Anonim. 2007. Rencana Bisnis Bank X Antasari Tahun 2007. Bank X, Bandar Lampung. Bank Indonesia. 2007. Statistik Ekonomi Keuangan Daerah Provinsi Lampung Tahun 2007. Bank Indonesia, Lampung.

Djinarto, B. 2000. Banking Asset Liability Management: Perencanaan, Strategi, Pengawasan dan Pengelolaan Dana. PT Gramedia Pustaka Utama, Jakarta. 
Iriawan, Nur dan Septin Puji Astuti. 2006. Mengolah Data Statistik Dengan Mudah Menggunakan Minitab 14. Penerbit Andi, Yogyakarta.

Kasmir. 2004. Manajemen Perbankan. Cetakan kelima. PT Raja Grafindo Persada, Jakarta.

Mattjik, A.A dan IM. Sumertajaya. 2002. Perancangan Percobaan Dengan Aplikasi SAS dan Minitab. Institut Pertanian Bogor, Bogor.

Riyadi, Selamet. 2004. Banking Assets and Liability Management. Edisi Kedua. Lembaga Penerbit Fakultas Ekonomi Universitas Indonesia, Jakarta.

Siska, Elfira. 2004. Analisis Kredit Modal Kerja dan Pengaruhnya Terhadap Laba Pada Bank Pembangunan Daerah Cabang Cibinong Jawa Barat. Skripsi pada Departemen Manajemen, Fakultas Ekonomi dan Manajemen, Institut Pertanian Bogor, Bogor. 